\title{
Colonization and growth of the toxic dinoflagellate Prorocentrum lima and associated fouling macroalgae on mussels in suspended culture
}

\author{
J. E. Lawrence ${ }^{1, *}$, J. Grant ${ }^{1}$, M. A. Quilliam ${ }^{2}$, A. G. Bauder ${ }^{2}$, A. D. Cembella ${ }^{2}$ \\ ${ }^{1}$ Department of Oceanography, Dalhousie University, Halifax, Nova Scotia B3H 4J1, Canada \\ ${ }^{2}$ Institute for Marine Biosciences, National Research Council Canada, 1411 Oxford Street, Halifax, \\ Nova Scotia B3H 3Z1, Canada
}

\begin{abstract}
We examined the role of substrate interactions and the biological activity of cultured shellfish on the settlement and growth of fouling macroalgae and the toxic epiphyte Prorocentrum lima. Six miniature live-mussel (Mytilus edulis) socks (30 cm long) and 6 dummy socks (created with empty mussel valves) were hung along a horizontal long-line at a sheltered coastal site in Nova Scotia, Canada. After 4 and 9 wk, 3 socks of each treatment were harvested and the biomass of fouling macroalgae and concentration of $P$. lima cells were determined. Macroalgal fouling, which was almost entirely Pilayella littoralis, was greater on the live-mussel socks than on the dummy socks (ANOVA, $\mathrm{p}<0.01$ ) after $9 \mathrm{wk}$. Densities of $P$. lima cells $\mathrm{g}^{-1}$ dry wt of fouling biomass were higher on the dummy socks than the live-mussel socks (ANOVA, p < 0.01) during the entire experiment. Liquid chromatography-mass spectrometry (LC-MS) analysis showed the epiphytic material to contain the diarrhetic shellfish toxins dinophysistoxin-1 (DTX1) and okadaic acid (OA), which had been previously identified in culture mussels from this site. The data suggest that mussel culture provides a microenvironment that favours the colonization and growth of macroalgae, but the growth and colonization densities of the epiphytic dinoflagellate are not directly dependent on that fouling biomass.
\end{abstract}

KEY WORDS: Biofouling community $\cdot$ Prorocentrum lima $\cdot$ Epiphytes $\cdot$ Mussel culture $\cdot$ Toxic microalgae

\section{INTRODUCTION}

Several studies have addressed the effect of shellfish culture on nutrient loading (Kaspar et al. 1985, Hatcher et al. 1994) and faunal diversity of the surrounding benthos, but few have examined the flora and fauna which are directly supported by shellfish culture installations (Lapointe et al. 1981, Tenore et al. 1982). The fouling communities associated with shellfish culture constitute a large percentage of the total biomass of farms; however, there is little known about the interactions between bivalve shellfish culture and these secondary communities.

${ }^{*}$ Present address: Earth and Ocean Sciences, University of British Columbia, 6270 University Blvd., Vancouver, British Columbia V6T 1Z4, Canada. E-mail: lawrence@ocgy.ubc.ca
The suspension of benthic organisms in the water column substantially modifies nutrient dynamics and substrate availability. The high density of suspensionfeeding organisms at shellfish culture sites increases dissolved nutrient levels (e.g. ammonium, urea) in the water column at the mesoscale level (Kaspar et al. 1985, Hatcher et al. 1994), and thereby provides a directly usable nitrogen source to fouling algae and phytoplankton. The lines used for suspension culture and the cultured organisms themselves also provide a surface area for attachment of epiphytic and epizootic organisms. Macroalgae benefit from having an attachment substrate in the upper water column where light levels support high photosynthetic production, and the nitrogen pool is enhanced by the metabolism of suspended mussels (Lapointe et al. 1981). Fauna also benefit from the protective habitat, which is rich in detritus. 
The toxic dinoflagellate Prorocentrum lima (also referred to as Exuviaella lima [McLachlan et al. 1997]) has been found living epiphytically on fouling macroalgae at shellfish aquaculture sites in Nova Scotia, Canada (Lawrence et al. 1998). This species produces toxins responsible for diarrhetic shellfish poisoning (DSP) (for review see Wright \& Cembella 1998), causing serious gastrointestinal distress when humans or other mammals ingest shellfish contaminated with the toxic alga. Although P. lima is a flagellated organism, it is a weak swimmer, and therefore lives primarily in habitats such as sandy sediments and on macroalgae (Fukuyo 1981). The physical structure created by suspended mussel culture and the fouling macroalgae associated with this culture provide an ideal substrate for the toxic dinoflagellate, and thus increases the potential for rapid growth.

This unique study marks the first attempt to examine the effect of mussel culture on the colonization and growth of the toxic dinoflagellate Prorocentrum lima, and of the macroalgae that provide a habitat for $P$. lima. The main goal was to determine if mussel culture simply provides a physical substratum, or if there is a more complex interaction that promotes the growth of the fouling community. This was achieved by comparing the accumulated macroalgal biomass and density of $P$. lima cells on experimental socks (nylon-mesh bags) stocked with live mussels, with that on dummy socks prepared with empty mussel shells. This study was conducted at an active mussel-culture site where mussel lines regularly become fouled with macroalgae and $P$. lima. To our knowledge, this study represents the first attempt to define growth, colonization, and secondary epiphytism of a toxic epi-benthic dinoflagellate suspended in the water column.

\section{MATERIALS AND METHODS}

Study site. The experiment was conducted at a commercial aquaculture lease near Indian Point, Nova Scotia, Canada $\left(44^{\circ} 27.25^{\prime} \mathrm{N}, 64^{\circ} 19.00^{\prime} \mathrm{W}\right)$. The site is in a well-protected, semi-enclosed embayment with approx. $10 \mathrm{~m}$ water depth and $2 \mathrm{~m}$ tidal range. Blue mussels (Mytilus edulis) were actively cultured at the farm throughout the experimental period in the summer of 1997.

Growth and harvest of epiphytes. On 8 June, 1997 (Julian Day 159), 6 miniature nylon-mesh socks $(30 \mathrm{~cm}$ long) each holding live mussels (mean no. $=177$, mean shell length $=3.15 \pm 0.43 \mathrm{~cm}$ ), were hung along a horizontal long-line $1 \mathrm{~m}$ below the surface. Six dummy socks were created by gluing empty mussel valves together with aquarium-grade silicone glue (732 Multi-Purpose Sealant, Dow Corning, Mississaga,
Canada), and attaching the shells to socking material. Unpublished laboratory experiments (J.E.L.) showed that this adhesive does not inhibit the growth of fouling algae. The dummy socks were created to reproduce the surface area and dimensions of the live-mussel socks. Although these dummy socks contained fewer mussels per length of socking material (mean no. = 114 , mean shell length $=3.15 \pm 0.43 \mathrm{~cm}$ ) than the livemussel socks, probably due to slightly different arrangement of the shells, the overall lengths and widths of the live and dummy socks were the same (30 $\mathrm{cm}$ long, $5 \mathrm{~cm}$ wide). The total available surface area for colonization of the socks was judged to be more important than the number of mussels. The dummy socks were hung randomly interspersed with the live-mussel socks at approx. $0.5 \mathrm{~m}$ intervals. Interspersing the 2 treatments over very short distances ensured that socks of both types encountered the same hydrodynamic regime.

After 4 and 9 wk (on 7 July and 14 August), 3 socks of each treatment were harvested by diving. After enclosing each sock in a large plastic bag, the socks were cut from the horizontal line, and recovered without losing any associated material. The mussels were scraped to collect the fouling macroalgae, and other associated algae suspended in the seawater collected in the bag were also harvested. Epiphytic microalgae were separated using a modified version of the method of Yasumoto et al. (1979). The bags were shaken to dislodge epiphytic microalgae from the macroalgae, and all material was poured through stacked 95 and $20 \mu \mathrm{m}$ sieves. The sieves were thoroughly rinsed using $0.2 \mu \mathrm{m}$ filtered seawater to remove micro-particulates and to dislodge algae for collection. Species of macroalgae collected on the $95 \mu \mathrm{m}$ sieve were identified, and then the material was rinsed with distilled water to remove salts, freeze-dried, and weighed. Microalgae that passed through the $95 \mu \mathrm{m}$ sieve were collected on the $20 \mu \mathrm{m}$ sieve, rinsed well with $0.2 \mu \mathrm{m}$ filtered seawater, and resuspended in a known volume of filtered seawater. A $20 \mu \mathrm{m}$ sieve was used because it was found to selectively retain the dinoflagellates of interest while passing through extraneous material (Lawrence et al. 1998). The sieved fraction was preserved with glutaraldehyde to a final concentration of $2 \%$, and species were enumerated in a $0.1 \mathrm{ml}$ Palmer-Maloney counting chamber under phase-contrast microscopy at $100 \times$ magnification.

To confirm toxicity of the epiphytic material, samples collected from the live-mussel socks following 9 wk deployment were also analyzed for DSP toxins by liquid chromatography with ion-spray mass spectrometry (LC-MS). For LC-MS analysis, $200 \mathrm{ml}$ aliquots of the suspended sample material were concentrated by centrifugation. Pellets were sonicated in 
10:1 (v/w) of $80 \%$ methanol, after which the extracts were centrifuged at $4000 \times g$ for $20 \mathrm{~min}\left(4^{\circ} \mathrm{C}\right)$ and supernatants filtered through $0.45 \mu \mathrm{m}$ Millipore Ultrafree-MC spin cartridges. Samples were analyzed by LC-MS using methods similar to those of Quilliam et al. (1996), except for slight modification of the mobile phase and column substitution: mobile phase: $0.2 \mathrm{ml} \mathrm{min}-150 \%$ aqueous acetonitrile, with $2 \mathrm{mM}$ ammonium formate and $0.2 \%(\mathrm{v} / \mathrm{v})$ formic acid; column: Keystone Hypersil-BDS-CB column, $50 \times 2 \mathrm{~mm}$. This LC-MS analysis yields the $\left(\mathrm{M}+\mathrm{NH}_{4}\right)^{+}$ions, $\mathrm{m} / \mathrm{z}$ 822.5 and 836.5 for okadaic acid (OA) and DTX1, respectively, which were measured by selected-ion recording. Quantitation was performed with reference to certified standards obtained from the CRM Program, Institute for Marine Biosciences, National Research Council, Halifax, Canada.

Water column measurements. Phytoplankton samples from the water column adjacent to the mussel lines were collected weekly during the experiment using a $7 \mathrm{~m}$ vertically-integrating pipe sampler. Collected water samples were preserved in 1:1 (v:v) formalin/acetic acid at a final concentration of $2 \%$, and $100 \mathrm{ml}$ aliquots were prepared for microscopic counting by the filter-transferfreeze method (Hewes \& Holm-Hansen 1983). All dinoflagellates and silicoflagellates were enumerated, and abundance of diatoms was estimated to the nearest order of magnitude.

Current-velocity measurements at the site were made using S4 current meters (InterOceans Ltd.) suspended $4 \mathrm{~m}$ above the bottom. Submerged floats were attached to the mooring lines to minimize wave interference. The first current meter was deployed on 20 June, 11 d into the experiment. Every $30 \mathrm{~min}$, a 7 min average of data was logged. This current meter was replaced on 10 July with another unit, which was programmed to log 7 min averages every hour. A pressuresensitive tidal gauge was also deployed for 1 wk during the study to determine tidal periodicity and amplitude. Watercolumn salinity and temperature were determined on a weekly basis by vertically casting a salinity, temperature, depth sensor (STD-12 Plus; Applied Microsystems) to $10 \mathrm{~m}$ at the site.

Data analysis. Macroalgal mass ( $g$ sock $^{-1}$ ) and Prorocentrum lima densities (cells $\mathrm{g}^{-1}$ macroalgae) were compared using 2 alternative 2-way analyses of variance (ANOVA) to determine if there were significant differences in biomass or density (cells unit mass $^{-1}$ ) within and between the experimental sock type and harvest dates. Analyses were also run on the data after correcting for the difference in the number of mussels between the 2 treatments. These data had to be converted using the natural logarithm transformation to pass tests for normality and equal variance. Statistical analyses were performed using SigmaStat (Version 2.0, 1997, Jandel Scientific, San Rafael, California, USA).

\section{RESULTS}

Macroalgal colonization and subsequent growth were rapid, resulting in complete coverage of the Mytilus edulis socks by the end of the experiment. Average macroalgal biomass on the live-mussel socks amounted to $4 \pm 1 \mathrm{~g}$ dry wt after $4 \mathrm{wk}$, and $30 \pm 4 \mathrm{~g}$ dry wt after 9 wk (Fig. 1A). The fouling material streamed off the mussel socks, occupying a large volume of the surrounding water (Fig. 2A). Biomass on the dummy socks was lower than on the socks containing live mus-
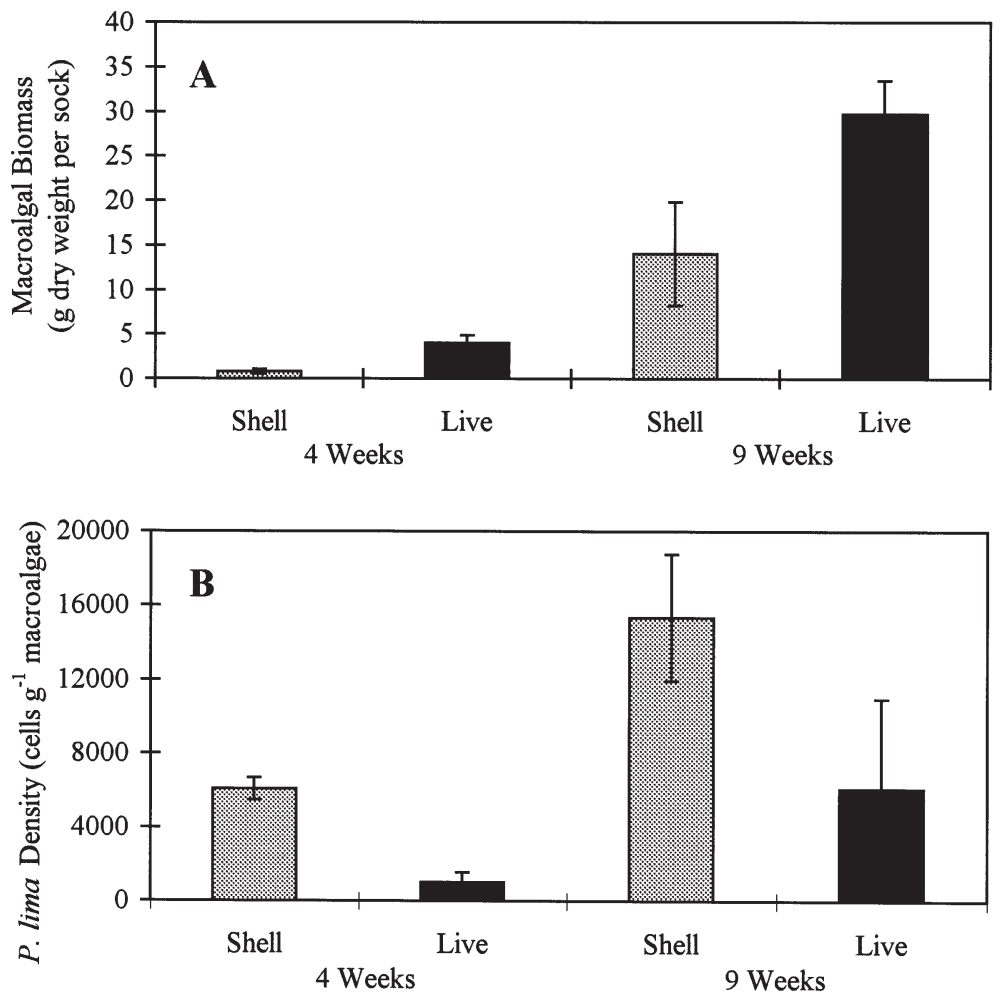

Treatment and Growth Period

Fig. 1. (A) Macroalgal biomass and (B) Prorocentrum lima densities accumulated on live-mussel (Mytilus edulis) and dummy socks during the $9 \mathrm{wk}$ of experiment. Values are average of 3 replicates; error bars are $1 \mathrm{SD}$ 

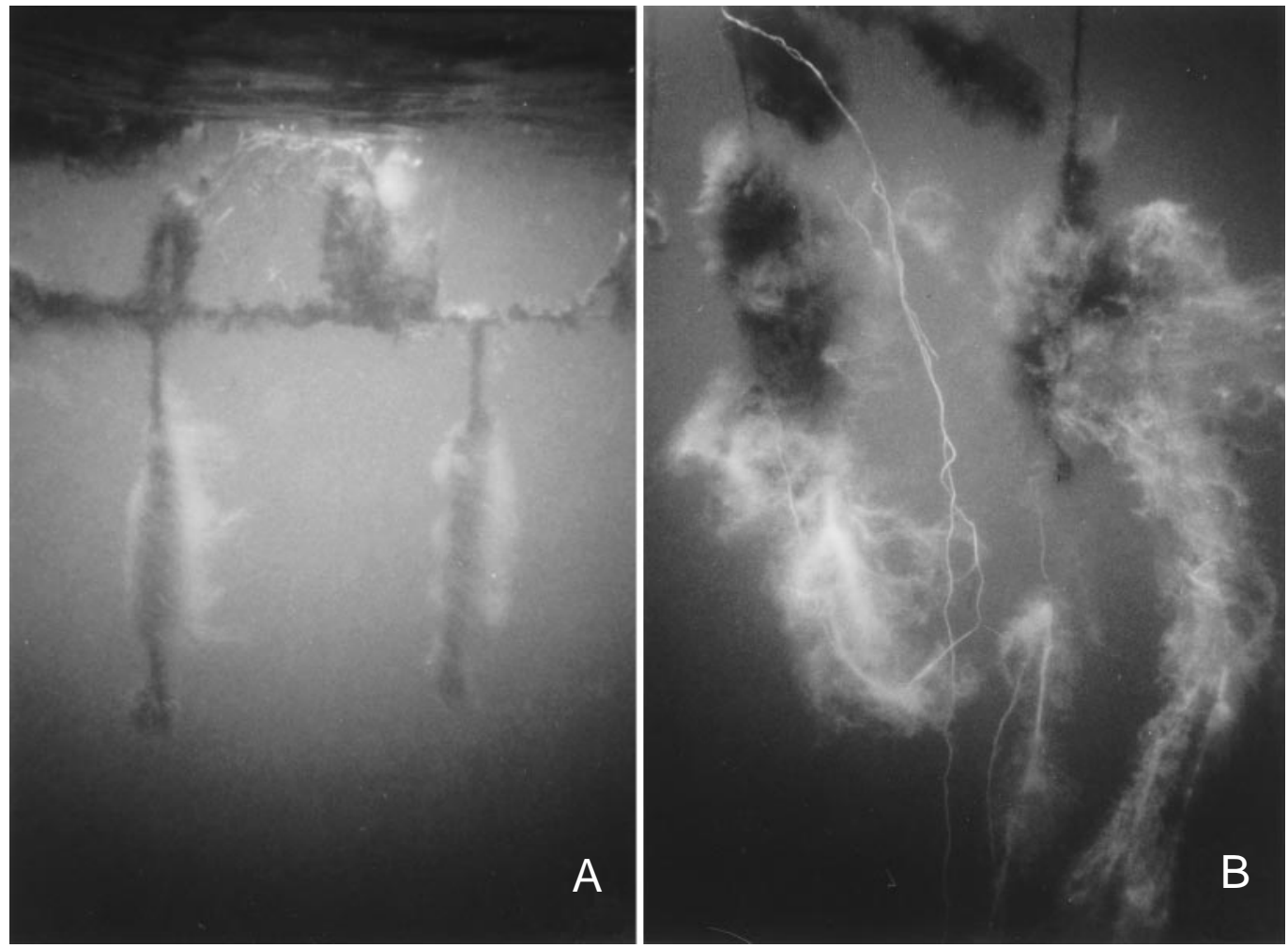

Fig. 2. Mytilus edulis. Experimental mussel socks following 9 wk of deployment. (A) Dummy socks; (B) live-mussel socks

sels $(\mathrm{p}<0.01)$, averaging $0.8 \pm 0.3 \mathrm{~g}$ dry wt after $4 \mathrm{wk}$, and $14 \pm 6 \mathrm{~g}$ dry wt after $9 \mathrm{wk}$ (Figs. 1A \& 2B) (Table 1). When corrected for the differences in the number of mussels between the 2 treatments, the biomass on the dummy socks was still significantly lower. The biomass was significantly greater after $9 \mathrm{wk}$ than after $4 \mathrm{wk}$ for both treatments $(\mathrm{p}<0.001$; Table 1$)$.

The composition of the macrophyte fouling community was limited to only a few taxa. The brown filamentous alga Pilayella littoralis was the dominant fouling species. There were small quantities (and negligible biomass) of the brown algae Chorda filum, Ectocarpus siliculosus and Fucus vesiculosus, the red

Table 1. Analysis of variance of the amount of macroalgal biomass found attached to the 2 experimental sock types on the 2 harvest dates $(n=3)$

\begin{tabular}{|lrrrr|}
\hline $\begin{array}{l}\text { Source of } \\
\text { variation }\end{array}$ & df & Sum of squares & \multicolumn{1}{c|}{$F$} & \multicolumn{1}{c|}{$\mathrm{p}$} \\
\hline Sock type & 1 & 226.176 & 21.766 & 0.002 \\
Harvest date & 1 & 1138.983 & 93.140 & $<0.001$ \\
Sock $\times$ date & 1 & 115.157 & 9.417 & 0.015 \\
$\begin{array}{l}\text { Residual } \\
\text { Total }\end{array}$ & 8 & 97.830 & & \\
\hline
\end{tabular}

algae Callithamnion corymbosum, Polysiphonia fibrillosa and Scagelia pylaisei, and the green alga Cladophora sericea. The sea grass Zostera americana was also present on a few socks after $9 \mathrm{wk}$.

The epiphytic microalgal community found on the macroalgae comprised numerous benthic pennate diatom species, including Fragilaria striatula, Licmophora sp., and Striatella unipunctata.

Prorocentrum lima was the only dinoflagellate species observed within the fouling material - on both experimental sock types and on both harvest dates. Densities after $4 \mathrm{wk}$ averaged $1 \times 10^{3}$ cells g $^{-1}$ dry wt fouling biomass on the live-mussel socks, compared to

Table 2. Analysis of variance of the densities of Prorocentrum lima collected from the 2 experimental sock types on the 2 harvest dates $(n=3)$

\begin{tabular}{|lrrrr|}
\hline $\begin{array}{l}\text { Source of } \\
\text { variation }\end{array}$ & df & Sum of squares & $F$ & $p$ \\
\hline Sock type & 1 & 153875570.083 & 17.062 & 0.003 \\
Harvest date & 1 & 154305580.083 & 17.110 & 0.003 \\
Sock $\times$ date & 1 & 13333100.083 & 1.478 & 0.259 \\
$\begin{array}{l}\text { Residual } \\
\text { Total }\end{array}$ & 8 & 9018429.250 & & \\
\hline
\end{tabular}




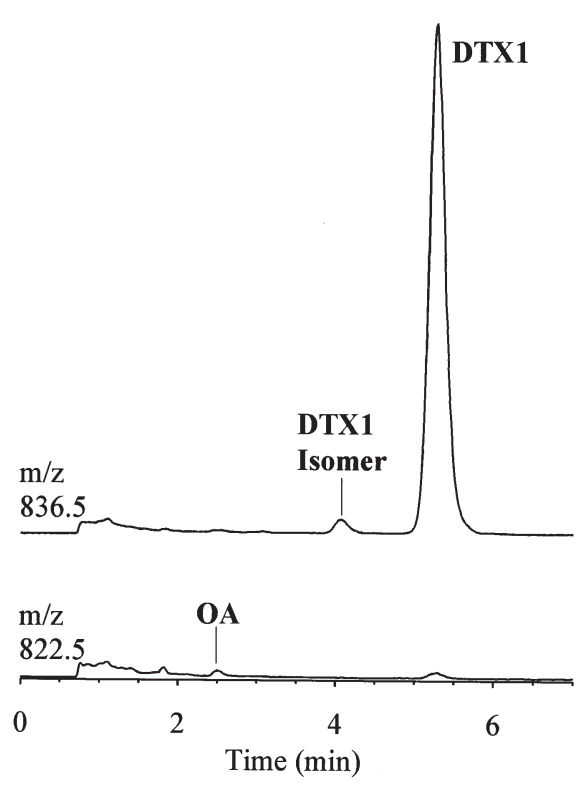

Fig. 3. Liquid chromatography-mass spectrometry analysis of epiphytic microalgal material collected from live-mussel (Mytilus edulis) socks after $9 \mathrm{wk}$ deployment. Dinophysis toxin-1 (DTX1) and okadaic acid (OA) peaks are indicated

$6 \times 10^{3}$ cells $^{-1}$ dry wt on the dummy socks (Fig. 1B). After $9 \mathrm{wk}$, the $P$. lima cell densities had significantly increased for both treatments $(\mathrm{p}<0.01)$ (Table 2); densities were $6 \times 10^{3}$ cells $\mathrm{g}^{-1}$ dry wt on the live-mussel socks, and $1.5 \times 10^{4}$ cells $\mathrm{g}^{-1}$ dry wt on the dummy socks (Fig. 1B). On both harvest dates, cell densities were significantly higher on the dummy-treatment socks than on the live-mussel socks $(p<0.01)$ (Table 2$)$, even when corrected for the difference in the number of mussels in each treatment. However, total numbers of $P$. lima cells per sock were not substantially different between the treatments, averaging approx. $2 \times 10^{6}$ cells.

The 3 samples of microalgae collected from the livemussel socks were all found to contain measurable quantities of dinophysistoxin-1 (DTX1), and trace levels of OA and an isomer of DTX1 (as yet unidentified) (Fig. 3). Mean cellular toxin levels were calculated by dividing the total amount of toxin extracted by the total number of cells found on each sock. Toxin levels estimated by this method averaged approx. $8.4 \mathrm{pg} \mathrm{cell}^{-1}$.

Diatoms dominated the phytoplankton during the

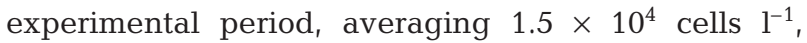
whereas dinoflagellates only comprised $7 \%$ of the total

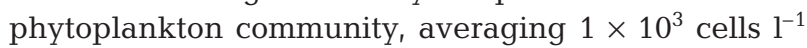
(Fig. 4). Prorocentrum lima was consistently present in the water column, although only in low concentrations. The maximum abundance was 45 cells $\mathrm{l}^{-1}$, and the average abundance was 14 cells $\mathrm{l}^{-1}$.

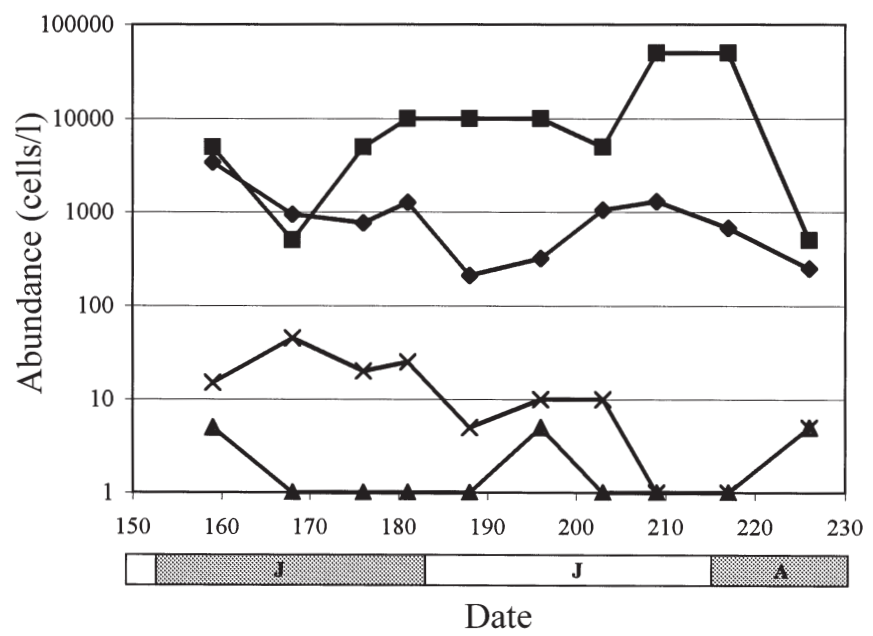

Fig. 4. Abundance of major phytoplankton taxa during experiment: (ロ) diatoms; $(\bullet)$ dinoflagellates; $(\mathbf{\Delta})$ silicoflagellates; $(\times)$ Prorocentrum lima. Abscissa $=$ Julian days

The water column at the site underwent typical latevernal-early-summer warming during the first $5 \mathrm{wk}$ of the experiment ( 8 June to 17 July). The temperature rose from 11 to $19^{\circ} \mathrm{C}$ at $1 \mathrm{~m}$ below the surface, where the experimental socks were located (Fig. 5). A sudden intrusion of cold bottom water destratified the column during the last week of July, and a further 4 wk were required for the temperature at $1 \mathrm{~m}$ depth to return to $18^{\circ} \mathrm{C}$.

Current velocity at $4 \mathrm{~m}$ above the bottom was taken as an index of water flow at the site. The maximum current speed observed while the socks were deployed was $5.1 \mathrm{~cm} \mathrm{~s}^{-1}$; average speed was $1.2 \mathrm{~cm} \mathrm{~s}^{-1}$. Flow oscillated with the tides along the axis at $53^{\circ} \mathrm{N}$, but did not show strong directionality. Recorded tidal periodicity was $12 \mathrm{~h} 32 \mathrm{~min}$, with an average amplitude of approx. $1.8 \mathrm{~m}$.

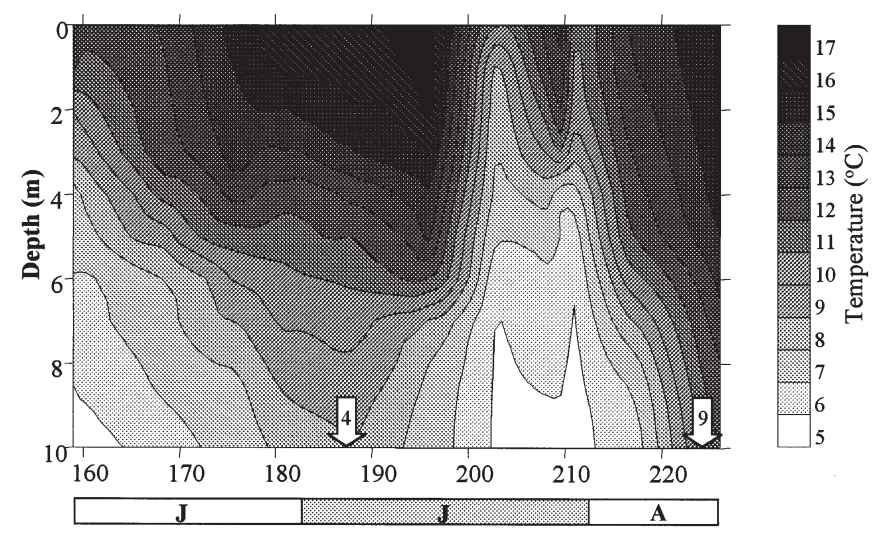

Date

Fig. 5. Temperature profiles for site during experimental period 


\section{DISCUSSION}

The microenvironment created by Mytilus edulis in suspended culture significantly increases the amount of accumulated fouling biomass compared to that of empty mussel shells. The pumping action of live mussels may alter the flow field and circulation of water around live-mussel socks, and thus enhance the colonization and subsequent attachment and growth of macroalgae. Excretion of nitrogenous compounds such as urea and ammonium into adjacent waters (Kaspar et al. 1985, Hatcher et al. 1994) by mussels could potentially create a micro-niche to stimulate algal growth. However, the macroalgae on the dummy socks did not exhibit this effect, despite the fact that they were only $0.5 \mathrm{~m}$ away from the live-mussel socks, and thus occupied essentially the same water mass as the macroalgae from the live-mussel socks. In any case, tidal flux and current speeds of $1.2 \mathrm{~cm} \mathrm{~s}^{-1}$ in the area would rapidly advect and mix any excreted compounds. This suggests that micro-scale nutrient enhancement does not entirely account for the difference in macroalgal biomass.

An epiphytic life-strategy may allow dinoflagellates growing on macroalgal substrates to directly assimilate growth-promoting substances from their hosts. An additional benefit may be provided from the proximity to shellfish excreta. In culture, macroalgal exudates have been found to enhance the growth of the epiphytic dinoflagellate species Gambierdiscus toxicus and Prorocentrum concavum (Carlson et al. 1984). Exposure to live mussels in the field study at Indian Point did not produce the same effect on the densities of $P$. lima as on the biomass of macroalgae on socks. It is possible that $P$. lima growth is already maximized in both treatments due to these exudates, and that the differences in cell densities are attributable to removal/growth dilution mechanisms that are treatment-specific.

The rapid growth of the macroalgal host for Prorocentrum lima may determine the cell density of the latter species. If the host macroalgae on the live-mussel socks grew significantly faster than the $P$. lima celldivision rate, then $P$. lima cell densities would decrease. This 'growth dilution' rate would be less on the dummy socks where the macroalgae were growing at a slower rate, thereby yielding a higher density of $P$. lima (per unit surface area). This effect is apparent, since the total number $P$. lima cells was not substantially different between the treatments, in spite of the large difference in macroalgal biomass. Microscopic observations revealed that growth of $P$. lima was clearly not limited by available surface area for colonization, although the densities on the host differed markedly according to the presence or absence of live mussels.
There are other conceivable explanations to account for the differences in Prorocentrum lima cell-density, which were outside the scope of the current investigations. The refuge provided by the higher biomass on the live-mussel treatments than on the control socks may have supported more fauna (e.g. amphipods) that fed upon P. lima and thereby controlled their density. Slight hydrodynamic differences between the treatments due to variation in shell-packing densities may also have affected the distribution of $P$. lima cells. The macroalgae fouling the live-mussel socks was observed streaming from the socks over a radius of ca $1 \mathrm{~m}$ by the 9th week of the experiment. This may have resulted in a differential rate of loss of $P$. lima from the fronds.

We expressed macroalgal colonization and growth as mass of macroalgae per sock. When these values were normalized to account for the different number of mussels between treatments, the differences were maintained. This normalization may not be appropriate, because it assumes that the number of mussels influences both the colonization and growth rates of the macroalgae. While surface area for attachment may affect colonization rates, it is doubtful that this would affect growth unless crowding density had been reached. This was clearly not the case in this experiment. Furthermore, the available surface area would not scale linearly with numbers of mussels because the mussels were packed around the socking material.

Variation in a number of hydrographic factors may have had an effect on the growth rates of both the macroalgae and Prorocentrum lima during the experiment. For example, an exceptional decrease in water temperature occurred on 19 July ( 5 wk into the experiment), and this would tend to affect algal growth rates, although perhaps not to the same extent for different taxa. Pilayella littoralis grows over a wide range of temperatures, with optimum growth occurring at $12^{\circ} \mathrm{C}$ (Müller \& Stache 1989). This drop in temperature may have maintained the conditions for maximal growth. While $P$. lima has been shown to survive at temperatures as low as $0^{\circ} \mathrm{C}$ and as high as $33^{\circ} \mathrm{C}$ (Morton \& Norris 1990, McLachlan et al. 1994), optimal growth rates for sub-tropical clones are sustained from 26 to $28^{\circ} \mathrm{C}$ (Morton et al. 1992), and strains from Nova Scotia grow more rapidly above $18^{\circ} \mathrm{C}$ (A. Cembella \& Y. Pan unpubl. data). Thus, the cold-water intrusion may have resulted in a temporary reduction in growth rate of $P$. lima during the second phase of the field experiment.

Currents at the Indian Point site oscillate with the tides, and there is very little residual flow. Therefore, unattached macroalgal filaments and associated Prorocentrum lima cells will tend to circulate within the embayment, remaining available to foul mussel 
culture installations, instead of being swept away in directional currents. Laboratory experiments using flumes have shown that the current speeds measured at the site are not likely to be strong enough to erode fouling algae after they have attached to the socks (Lawrence et al. unpubl.). Selection of aquaculture sites that do not favour fouling, such as those with high flow rates or frequent hydrodynamic disruptions (e.g. exposure to storm surges), might reduce the potential for culture lines to become colonized by toxic epibenthic dinoflagellates and thereby reduce the resultant risk of shellfish toxicity.

The consistent but low numbers of Prorocentrum lima observed in the water column suggests that colonization of the socks by this organism did not result from a single sporadic event. The observed colonization and growth are most likely to be indicative of a continual supply of both the fouling macroalgae and the dinoflagellate to the site by advection and/or erosion and resuspension. Since the dinoflagellate was found inhabiting the macroalgae after only $4 \mathrm{wk}$, the primary method of colonization of the mussel socks by this dinoflagellate is probably as an epiphyte on drifting macroalgae, followed by in situ growth, rather than by direct colonization of attached macroalgae after they have attached to the socks. This hypothesis is also supported by the fact that the density of $P$. lima on the 2 sock treatments was different. If $P$. lima cells were supplied continually from the water column and independently of the macroalgae, then one would expect to find similar densities of $P$. lima on the control and livemussel socks.

The primary focus of this field study was to examine the environmental effects on algal colonization, biomass production, and growth, and not to investigate micro-environmental effects on toxicity of Prorocentrum lima. Cellular toxin levels are a function of the growth rate of the toxin-producing organism, and toxin production rates are determined by the interplay between genetic and environmental factors (Wright \& Cembella 1998). It was not possible to establish the respective role of in situ growth rates of $P$. lima and micro-environmental factors in determining toxin production with this experimental design. Therefore, no attempt was made to track variation in cell-toxin content over time or between control versus experimental treatments. Nevertheless, it was important to ascertain that the strain of $P$. lima collected from the field site was indeed toxigenic. The cellular toxin levels detected in the field material agree well with published values for cultured $P$. lima isolated from this site (McLachlan et al. 1994). There are, however, noteworthy differences between the toxin profile of an isolate (Strain $\mathrm{Pa}$ ) previously cultured from this site and that of the bulk field samples collected in this study. The cultured isolate of $P$. lima from Indian Point was found to produce relatively high amounts of OA, and significantly lower concentrations of DTX1 (McLachlan et al. 1994) than contained in the field samples reported here. The high DTX1/OA ratio detected in the bulk epiphytic material is the first report that corresponds to the profile found in mussels collected from the Indian Point site in 1990, after human cases of shellfish poisoning (Quilliam et al. 1993). This toxic event represents the first confirmed incidence of DSP in North America. The organism responsible for producing the DSP toxins found in the mussels was not conclusively determined at the time, however, P. lima was later suspected (Jackson et al. 1993).

In conclusion, mussels suspended in the water column provide a substrate that favours the colonization and growth of macroalgae. Colonization and growth of the toxic dinoflagellate, Prorocentrum lima are not directly dependent on the stimulatory presence of live mussels, but the cell density is a function of the magnitude and growth of the fouling biomass. Selecting for sites that do not favour fouling, such as those with high flow rates or frequent disturbances, or physically reducing the amount of biofouling already present on mussel lines might help reduce the risk of mussel contamination by DSP toxins originating from epiphytic dinoflagellates. Further research into the mechanism by which the mussels ingest epiphytic microalgae will help in resolving the specific conditions that may lead to toxicity.

Acknowledgements. We thank C. J. Bird for macroalgal identification and P. MacPherson for deploying the S4-current meters. We are particularly indebted to P. Darnell of Indian Point Marine Farms for the donation of the mussels, help in setting up the experimental sock line and mooring instruments, and continued support of this research. This publication is NRC No. 42325 .

\section{LITERATURE CITED}

Carlson RD, Morey-Gaines G, Tindall DR, Dickey RW (1984) Ecology of toxic dinoflagellates from the Caribbean Sea: effects of macroalgal extracts on growth in culture. In: Ragelis EP (ed) Seafood toxins. American Chemical Society, Washington, DC, p 271-287

Fukuyo Y (1981) Taxonomical study on benthic dinoflagellates collected in coral reefs. Bull Jap Soc Scient Fish 47: 967-978

Hatcher A, Grant J, Schofield B (1994) Effects of suspended mussel culture (Mytilus spp.) on sedimentation, benthic respiration and sediment nutrient dynamics in a coastal bay. Mar Ecol Prog Ser 115:219-235

Hewes CD, Holm-Hansen O (1983) A method for recovering nanoplankton from filters for identification with the microscope: the filter-transfer-freeze (FTF) technique. Limnol Oceanogr 28:389-394

Jackson AE, Marr JC, McLachlan JL (1993) The production of diarrhetic shellfish toxins by an isolate of Prorocentrum 
lima from Nova Scotia, Canada. In: Smayda T, Shimizu Y (eds) Toxic phytoplankton blooms in the sea. Elsevier, New York, p 513-517

Kaspar HF, Gillespie PA, Boyer IC, MacKenzie AL (1985) Effects of mussel aquaculture on the nitrogen cycle and benthic communities in Kenepuru Sound, Marlborough Sounds, New Zealand. Mar Biol 85:127-136

Lapointe BE, Niell FX, Fuentes JM (1981) Community structure, succession, and production of seaweeds associated with mussel-rafts in the Ria de Arosa, N.W. Spain. Mar Ecol Prog Ser 5:243-254

Lawrence JE, Bauder AG, Quilliam MA, Cembella AD (1998) Prorocentrum lima: a putative link to diarrhetic shellfish poisoning in Nova Scotia, Canada. In: Reguera B, Blanco J, Fernandez ML, Wyatt $\mathrm{T}$ (eds) Harmful microalgae. Xunta de Galicia and UNESCO, Santiago de Compostela, p 78-79

McLachlan JL, Marr JC, Conlon-Kelly A, Adamson A (1994) Effects of nitrogen concentration and cold temperature on DSP-toxin concentrations in the dinoflagellate Prorocentrum lima (Prorocentrales, Dinophyceae). Nat Toxins 2: $263-270$

McLachlan JL, Boalch GT, Jahn R (1997) Reinstatement of the genus Exuviaella (Dinophyceae, Prorocentrophycidae) and an assessment of Prorocentrum lima. Phycologia 36: 38-46

Morton SL, Norris DR (1990) Role of temperature, salinity, and light of the seasonality of Prorocentrum lima (Ehrenberg) Dodge. In: Granéli E, Sundström B, Edler L, Anderson, DM (eds) Toxic marine phytoplankton. Elsevier, New York, p 201-205

Morton SL, Norris DB, Bomber JW (1992) Effect of temperature, salinity and light intensity on the growth and season-

Editorial responsibility: Otto Kinne (Editor),

Oldendorf/Luhe, Germany ality of toxic dinoflagellates associated with ciguatera. J Exp Mar Biol Ecol 157:79-90

Müller DG, Stache B (1989) Life history studies on Pilayella littoralis (L.) Kjellman (Phaeophyceae, Ectocarpales) of different geographical origin. Bot Mar 32:71-78

Quilliam MA, Gilgan MW, Pleasance S, DeFreitas ASW, Douglas D, Fritz L, Hu T, Marr JC, Smyth C, Wright JLC (1993) Confirmation of an incident of diarrhetic shellfish poisoning in Eastern Canada. In: Smayda TJ, Shimizu Y (eds) Toxic phytoplankton blooms in the sea. Elsevier, New York, p 547-552

Quilliam MA, Hardstaff WR, Ishida N, McLachlan JL, Reeves AR, Ross NW, Windust AJ (1996) Production of diarrhetic shellfish poisoning (DSP) toxins by Prorocentrum lima in culture and development of analytical methods. In: Yasumoto T, Oshima Y, Fukuyo F (eds) Harmful and toxic algal blooms. IOC-UNESCO, Paris, p 289-292

Tenore KR, Boyer LF, Cal RM, Coral J, Garcia-Fernandez C, Gonzalez N, Gonzalez-Gurriaran E, Hanson RB, Iglesias J, Krom M, Lopez-Jamar E, McClain J, Pamatmat MM, Perz A, Rhoads DC, de Santiago D, Tietjen J, Westrich J, Windom HL (1982) Coastal upwelling in the Rias Bajas, NW Spain; contrasting the benthic regimes of the Rias de Arosa and de Muros. J Mar Res 40:701-772

Wright JLC, Cembella AD (1998) Ecophysiology and biosynthesis of polyether marine biotoxins. In: Anderson DM, Cembella AD, Hallegraeff GM (eds) Physiological ecology of harmful algal blooms. Springer-Verlag, New York, p 427-451

Yasumoto T, Inoue A, Bagnis R, Garcon M (1979) Ecological survey on a dinoflagellate possibly responsible for the induction of ciguatera. Bull Jpn Soc Sci Fish 45: 395-399

Submitted: March 2, 1999; Accepted: January 6, 2000

Proofs received from author(s): July 17, 2000 